\title{
VERSCHUIVING VAN MAATSCHAPPELIJKE MACHT
}

\author{
door Prof. Dr P. Kuin
}

James Burnham, geboren 1905, schreef dit boek op zijn 35e jaar, nadat hij in Princeton en Uxford had gestudeerd, begonnen was aan New York University college te geven en een tijdschrift had opgericht, dat zich ten doel stelde Europese schrijvers in Amerika bekend te maken. Een vereuropeeste Amerikaan dus; hij zegt in een later boek b.v. ,Iedereen die een paar uur naar de Amerikaanse radio luistert beseft wat een vreselijke prijs het voor de rest van de wereld zou zijn, als zij - om gered te worden - zich zou moeten veramerikaansen".

Ondanks zijn Oxfordse jaren is Burnham alles behalve Angelsaksisch in zijn denken, tenminste in dit jeugdwerk ,"The Managerial Revolution". Het lijkt eerder of hij in het Duitsland van de twintiger jaren zijn vorming had gekregen: het boek is historisch-materialistisch van methode, geforceerd verstandelijk van toon (in de trant van: wat $U$ en ik hiervan vinden doet niets ter zake, het komt er op aan wat er gebeurt) en van een monumentale zelfverzekerdheid.

De verklaring hiervoor is, dat de schrijver in zijn jonge jaren gepakt werd door het Marxisme en enkele jaren redacteur is geweest van "De Nieuwe Internationale", het orgaan der Trotskisten. Een dissidente communist dus, gedrenkt in de dogmatiek van het marxisme, maar intelligent genoeg om te zien, dat een van de voornaamste stellingen daarvan in de praktijk niet uitkwam. Deze stelling was, dat op de afbraak van het kapitalisme automatisch het socialisme volgt - m.a.w. dat het socialisme het enige alternatief is voor het kapitalisme. Wat hij in Rusland zag was de heerschappij van de bureaucratie in plaats van de heerschappij van de massa. Bureaucratie, dat waren de organisatoren van het politieke en economische leven. Soortgelijke verschijnselen zag hij in het nationaalsocialistische Duitsland, het fascistische Italië, en het Amerika van de New Deal. Overal verloren de kapitalistische machthebbers - aandeelhouders en eigenaren van bedrijven, alsmede hun gesalarieerde vertegenwoordigers - terrein en vond een verschuiving van macht plaats naar de leiders van overheidsdiensten en bedrijven, naar de rijks- en planbureaux. Hetzelfde kon men bespeuren in de grote particuliere corporaties - een verschuiving van feitelijke zeggenschap van de financiële sfeer naar de sfeer van de productie. De New Deal deed zijn invloed voelen niet alleen in de staat maar ook in het bedrijfsleven. Toch is het vermoedelijk vooral het voorbeeld van Rusland geweest dat deze marxistische intellectueel het eerst op de gedachte heeft gebracht, dat niet de arbeidersklasse de opvolgster is van de kapitalistische bourgeoisie, maar de klasse der "managers".

$\mathrm{H}_{\mathrm{ij}}$ vindt dit niet bijzonder mooi of aangenaam, eerder het tegendeel, maar hij ziet het als onontkoombaar. Ook heeft hij geen illusies over de vorm of het gehalte van een managers maatschappij. De nieuwe klasse zal volgens hem haar heerschappij vestigen door eerst de kapitalisten te verslaan, dan de massa te knechten en ten slotte - in voortdurende strijd met de klassegenoten in andere landen - de staatsmacht gebruiken om zichzelf de privileges toe te kennen van zeggenschap over de productie en voorrang bij de verdeling van het maatschappelijke inkomen. $Z_{i j}$ zullen m.a.w. niet alleen de nieuwe meesters maar ook de nieuwe rijken $z$ ijn.

Dit lijkt een aantrekkelijk vooruitzicht voor aanstaande managers. Misschien heeft de S.E.F. daarom dit onderwerp wel uitgekozen? Maar laten 
de economen zich niet vergissen: in Burnham's theorie hebben zij veel minder kans om in de nieuwe klasse te worden opgenomen dan de ingenieurs.

Burnham onderscheidt namelijk vier groepen in de maatschappelijke voortbrenging:

a. zij die de productie organiseren;

b. zij die grondstoffen kopen, producten verkopen, de financiering verzorgen;

c. zij die de holding companies beheren;

d. zij die de aandelen bezitten.

De laatsten liggen voornamelijk in de zon in Florida of varen met een jacht in de Middellandse Zee.

De handelsmensen en de financiers ontlenen hun functie vooral aan de kapitalistische productiewijze en zullen met deze verdwijnen, behalve degenen die opgaan in de enig overblijvende groep: die van de technici en organisatoren. Dat zijn dus Burnham's managers. Zijn leer is eigenlijk een marxistisch gefundeerde technocratie.

$\mathrm{H}_{\mathrm{ij}}$ ziet de politieke bureaucraten als het wisselende element, de organisatoren van de productie als het blijvende. Over de Duitse emigranten merkt hij b.v. op: ,,daaronder waren zakenlieden, schrijvers, intellectuelen, maar geen ,managers". Die kregen toen hun kans om de staat te veroveren en de productie te organiseren. Terwijl de massa werkt, de sociologen de theorie der toenemende overheidsbemoeiing opbouwen, de journalisten en sprekers haar propageren en de politici zichzelf voor het voetlicht dringen, bouwen de ambtenaren van departementen en rijksdiensten, de directies en ingenieurs der staatsbedrijven en de leiders der planbureaux hun machtsposities op. Hetzelfde gebeurt in de grote industriële corporaties: de productie wordt steeds ingewikkelder en degenen die haar beheersen zijn de dragers van de machtsposities van morgen". Aldus Burnham.

Hier voelen we al de kriebel van de critiek, want deze theorie klopt niet met de werkelijkheid. Het minst in het bedrijfsleven. De technici en de productieleiders zijn daar niet de machtigen, noch in het heden, noch - voor zover we dat kunnen bekijken - in de naaste toekomst. In de grote industriële bedrijven hebben we de volgende opklimming van inkomen en invloed van onder af:

1. de researchwerkers;

2. de productieleiders;

3. de bedrijfseconomen (accountants, organisatoren, specialisten);

4. de kooplieden:

5. de directeuren: de algemene overkoepelende leiders.

In de overheidsdiensten en bedrijven zien wij iets soortgelijks, misschien met een iets zwakker accent op het commerciële. Ook dit zelfs dubieus: in de overheidsdienst was jarenlang de best betaalde functionaris de directeur van het verkoopkantoor van een overheidsbedrijf.

Hoe komt Burnham tot een zo tastbare vergissing? Door zijn marxistische instelling. Maatschappelijke verhoudingen richten zich naar de productieverhoudingen, de productieverhoudingen naar de productiekrachten. Wie dus de hand heeft aan de handles van het productie-apparaat, bezit de sleutels van de maatschappelijke macht.

De marxistische methode heeft de schrijver op nog meer punten op een dwaalspoor geleid. Zo zag hij in de toekomst drie grote centra van wereld- 
politieke macht: Amerika rondom de Verenigde Staten, Europa rondom Duitsland en Azië rondom Japan. Waarom? Omdat op het ogenblik waarop hij dit schreef (1940) Duitsland in Europa en Japan in Azië technischeconomisch het hoogst ontwikkeld waren. Dat het zwaartepunt van Azië in het achterlijke China zou komen te liggen was van zijn standpunt onlogisch. Hijvergat, dat het even onlogisch geweest zou zijn, in 1914 te voorspellen dat het einde van het kapitalisme het eerst zou komen in Rusland, een land, waar het kapitalisme het feodalisme nog niet eens helemaal had verdrongen. Natuurlijk mag men een socioloog niet verwijten dat hij de afloop van de oorlog verkeerd heeft gezien. Burnham heeft trouwens in een voorwoord bij de vertaling van zijn boek in 1946 toegegeven, dat verscheidene politieke voorspellingen verkeerd waren uitgekomen omdat hij zich in 1940 ,nog niet voldoende had vrijgemaakt van de marxistische opvatting, dat de politiek qeheel mechanisch ondergeschikt is aan de economie". Ook had hij onder Trotsky's invloed de kracht van het Sovjetregieme onderschat.

Maar als hij dan de politieke ontwikkeling verkeerd heeft gezien, in de economische ontwikkeling mag hij zich als historisch materialist niet vergissen. $Z_{i j}$ immers levert, zoals hij herhaaldelijk zegt, de bewijzen op voor de iuistheid van zijn theorie der maatschappelijke machtsverschuiving.

Toch bekruipt ons een gevoel van scepsis, wanneer hij de nabij zijnde ondergang van het kapitalisme aantoont door als bewijzen o.a. aan te voeren:

a. de voortdurende massale werkloosheid in de kapitalistische landen, die ook in de oorlog niet zou kunnen verdwijnen;

b. de dalende tendens in de conjunctuurbeweging, waardoor iedere volgende hoogconjunctuur lager komt te liggen dan de vorige;

c. het einde van de vrije internationale handel en het opkomen van de vormen van ruilhandel, zoals die in Duitsland, Italië en Rusland gebruikelijk waren;

d. het achterwege blijven van technische vernieuwing in het kapitalistische bedrijfsleven.

Wanneer wij heden ten dage gebrek aan arbeidskrachten, ongekende hooqconjunctuur, afbraak van handelsbelemmeringen en stormachtige tech. nische vernieuwing opmerken, kunnen wij moeilijk aannemen, dat dit reeds de bloeivormen zijn van de nieuwe klassenmaatschappij, die Burnham ziet als de opvolgster van het kapitalisme en die volgens hem omstreeks het jaar 1965 haar consolidatie zou vinden. Wel verre van nog slechts tien jaar van haar definitieve ondergang af te staan, lijkt het economische stelsel, dat wij kennen als kapitalistisch, nog vol leven te zitten.

$\mathrm{Nu}$ kan men zeggen, goed, Burnham heeft zich in de fase vergist, of in het tempo. Misschien komt het einde van het kapitalisme pas in een volgende crisis of na een volgende oorlog. Maar het komt niet in de eerste plaats aan op fase of tempo. De hoofdzaak is, of zijn algemene theorie juist is. Moeten wij aannemen, dat er een nieuwe klasse in opkomst is, die van de productieleiders - een klasse die met behulp van de staat haar macht zal vestigen, haar privileges zal verzekeren en andere klassen uitbuiten - een en ander naar analogie van wat andere klassen vóór haar hebben gedaan?

Onze waardering van Burnham's theorie hangt grotendeels af van onze waardering van de marxistische geschiedbeschouwing. Het thema dat zijn boek domineert, is de (door hem overigens nergens geciteerde) eerste zin 
van het Communistisch Manifest: „.De geschiedenis van alle samenleving is tot dusver een geschiedenis van klassenstrijd".

Wanneer wij dat niet aanvaarden, kunnen wij de theorie van Burnham niet in haar geheel aanvaarden, want hij bedoelt niet zo maar te zeggen dat de managers meer macht krijgen: hij bedoelt dat zij zich als heersende klasse $z$ ullen vestigen en andere klassen zullen uitbuiten.

$\mathrm{Nu}$ is het hier niet de plaats de marxistische geschiedbeschouwing uitvoerig te bestrijden. Kort gezegd kunnen wij zeggen, dat zij eenzijdig is, alles naar één kant trekt, causaliteiten forceert waar ze niet zijn en tekort doet aan de veelvormigheid van het leven en zijn impulsen. Juist is, dat elke maatschappij een zekere structuur aanneemt, maar onjuist dat die structuur in de eerste plaats instrument is voor de heersende klasse om de andere uit te buiten, of dat de hele ontwikkeling van die maatschappij neerkomt op een strijd om de macht tussen de verschillende geledingen.

Een voorbeeld van Burnham's eenzijdigheid is, dat hij ongelijke inkomensverdeling als een teken ziet van uitbuiting. Als in een Universiteit een hoogleraar dus meer verdient dan een bode, komt dat doordat de hoogleraar behoort tot een klasse die de klasse, waartoe de bode behoort, uitbuit. Burnham's hele beschouwingswijze is volstrekt on-economisch. Vandaar ook zijn eenzijdige uitleg van het begrip manager, in de zin van productieleider. Ook spreekt hij over openen en sluiten van fabrieken enz. door de „kapitalisten", alsof het daden van willekeur waren.

Het beqrip ,,markt", zowel voor goederen als voor diensten is hem vreemd. Dat er voor sommige difnsten een hogere waardering ontstaat dan voor andere, omdat $z \mathrm{ij}$ b.v. meer bijdragen tot de maatschappelijke voortbrenging, of relatief schaarser zijn, ziet hij niet. Voor hem is de verdeling uitsluitend een kwestie van macht, hetzij direct hetzij indirect via de maatschappelijke gewoonten, die door het belang van de heersende klasse worden bepaald.

Wij kunnen hierbij aanknopen, om het antwoord te geven op Burnham's stelling. Symptomatisch is, wij zagen het reeds, dat hij als de eiqenlijke managers de productieleiders ziet. Nu klopt het niet met de werkelijkheid, dat dat de invloedrijke mensen $z$ ijn. $Z_{i j}$ zijn een groep van managers uit velen. Wie zijn dan wel de machtigen? Op het oog: de mensen die hoe langer hoe minder weten van hoe langer hoe meer onderwerpen. In de regeringsdienst: niet de leiders der overheidsbedrijven of planbureaux, maar de hoofdambtenaren van departementen of - in geval van decentralisatie - van de rijksbureaux, de filialen van departementen voor een speciaal gebied. Ook daar weer niet de specialisten, maar de algemene beleidsfunctionarissen: afdelingshoofden, directeuren, directeuren-generaal. In het bedrijfsleven: niet de specialisten, maar de directeuren, die zich voor elk moeilijk qeval door specialisten laten bijstaan.

Hoe komt dat? Is dit een kwestie van macht, slimheid en protectie? Dat alles speelt een rol, maar een ondergeschikte. De kern is, dat in die algemene ",grote" functies de mensen terecht komen, die beschikken over een der meest schaarse natuurgaven die er bestaan: het vermogen om mensen te leiden, een aroep bij elkaar te houden, een organisatie te laten functioneren, verschillende specialisten te overkoepelen, mensen van allerlei slag vertrouwen in te boezemen, moeiliike technische, organisatorische, financiële, menselijke problemen in grote lijnen te doorzien en op te lossen, aan te voelen waar iets mis dreigt te gaan, te zien waar het geheel naar toe moet, te zorgen dat er gehandeld wordt, op kleinigheden te letten en grote lijnen toch te zien, medewerkers te inspireren tot inspanning en loyauteit.

$\mathrm{ma} \mathrm{b}$ blz. 6 
Dit soort leiderschap is schaars en altijd schaars geweest. Het heeft in verschillende tijden verschillend emplooi gevonden: in de vroonhoeve, in het stadsbestuur, in de fabrieks- of handelszaak, in de moderne corporatie, in de vakbeweging, in de politieke partij.

De mensen, die deze gave bezitten, komen op de leidende plaatsen en genieten - vooral als zij zich in de sfeer van de maatschappelijke voortbrenging bewegen - de hogere inkomens. Niet altijd de hoogste: er zijn accumulaties van bezit, voortvloeiend uit erflating en vroegere usurpatie.

De bijkomende kwaliteiten die men moet bezitten, wisselen met de eisen van de tijd:

Physieke moed in de riddertijd;

Politieke slimheid en/of krijgskunde in de tijd van de statenvorming;

Handelsgeest en ontdekkingsdrang in de 17 e eeuw;

Technisch/kapitalistisch ondernemerschap in de 19e eeuw;

Financieel organisatievermogen en juridisch vernuft in de tijd van de opkomst van de grote onderneming in de eerste helft van de 20ste eeuw, misschien in de komende tweede helft van de 20ste eeuw;

de șave om een concurrerend bedrijf sociaal te integreren, of om technische problemen geheel nieuw te zien.

Onmiddellijk onder deze algemene leiders staan, in waardering op de markt, de mensen die voelen wat de samenleving vraagt: in zeer concrete zaken cle commerciële managers, in wijder verband politieke en andere adviseurs, de ",policy makers", de mensen met het juiste maatschappelijke instinct.

Dáăronder komen de ,,brains", de knappe koppen en specialisten.

Wat Burnham nu ziet is hetzelfde als Berle and Means - The modern Corporation and private property (1930) - al hadden gesignaleerd, de scheiding tussen eigendom en beheer in de moderne vennootschap. Een dergelijke scheiding was in de geschiedenis al eens vertoond, de feitelijke vervanging van de edele door zijn meier, van de leenheer door zijn hofmeier, die soms, zoals in het geval van Pepijn de Korte, de nominale koning van de troon drong. De verklaring hiervoor was vermoedelijk dat in die tijd organisatievermogen nodiger was geworden dan ridderdeugd. Thans is organisatievermogen (financieel, commercieel-technisch) nodiger dan kapitalistisch ondernemerschap naar de $19 e$ eeuwse trant.

Wat wij zien is dus een verschuiving in accent van de bijkomende eigenschap - geen nieuwe klasse, maar een nieuw type leiderschap. Dit type is meer onderling uitwisselbaar in verschillende maatschappelijke milieu's. Tussen de kapitalistische ondernemer en de deftige hoofdambtenaar van vóór 1914 gaapte een wijde kloof. Tussen de moderne manager in een grote onderneming of in een grote overheidsdienst niet meer. Zelfs onder de bezoldigde bestuurders van politieke partijen en vakverenigingen vindt men dit soort leiders.

Het doordringen in deze leidende groep is niet afhankelijk van bezit maar dat was het ook in de $19 \mathrm{e}$ eeuw eigenlijk niet. Vele later deftige families hadden een energieke smid of andere handwerksman die fabrikant werd, tot voorvader. De penetratie is echter evenzeer als vroeger afhankelijk van schaarse eigenschappen.

Democratie komt er in zoverre weinig aan te pas, dat de algemene wet der selectie, die van coöptatie en (gedeeltelijk) assimilatie is. Deze wet zien wij ook werken in andere dan economische milieu's: de staatsdienst, het leger, het onderwijs, de politiek, de vakbeweging, het verenigingsleven. Maar wie in sterke mate de gaven bezit waar zijn tijd om vraagt, dwingt de coöptatie als het ware zelf af. 